\title{
The Outcome of Postnatal Exercise on Depressed Women Six to 16 Weeks after Delivery in Sukabumi City, 2014: Pre and Post Intervention Study
}

Poerwanto Siswo*, Endar Prasatwati, Insriwati, Imam Waluyo, Arsyad Subu M and Sri Harsodjo

Physiotherapy Study Program, Binawan Institute of Health Sciences, Jakarta, Indonesia

\begin{abstract}
Evidence shows that psychic disturbances among women during pregnancy and postnatal period causes depression syndrome. Risk factor of postnatal depression includes depression and anxiety and stressful life experience during that risky period. Statistic from the city of Sukabumi indicated the unavailability of data on post natal depression among women. The study question is to evaluate the outcome of exercise among depressed post natal women in Sukabumi city in 2014, during six to sixteen weeks after delivery. The study design is pre-and post-outcome evaluation of post natal exercise intervention. Out of 120 target population obtained from the main Cross Sectional Survey, it was selected study sample of 14 depressed women. A regime of post natal exercise was given to the sample, consisted of postnatal exercises for 10 weeks @ 3 sessions per week or 30 sessions with 30-50 min exercise per session done in the morning before 10 O'clock and in the afternoon after $3 \mathrm{p} . \mathrm{m}$. The outcome variable is EPDS score before and after intervention of post natal exercise. The cut-off point to determine possible depression is EPDS score of $\geq 10$. Univariate analysis was conducted on socio-demographic characteristics of the sample. Bivariate analysis was done to test a null hypothesis that EPDS is the same pre-and post-exercise, assuming that no other variables confound the intervention. The paired t-test results indicated that the EPDS decreased significantly 7.6 points $(p<0.05)$ after 10 weeks from $13.15(10.66,15.64)$ down to $5.55(4.20,6.90)$. After 10 weeks of postnatal exercise conducted, out of 14 subjects there was one subject who remained depressed, but the other 13 women were normal $(p<0.05)$. Software used was SPSS $v 17$ trial version. The study infers that postnatal exercise routinely and regularly may be promoted to be conducted by local health services.
\end{abstract}

Keywords: Postnatal exercise; Postnatal depression; EPDS; Bivariate analysis

\section{Introduction}

According to Gavin et al. [1], a psychic disturbance among women during pregnancy and during postnatal period causes depression syndrome indicated by various emotional disturbances, cognitive and behaviour, which is repeated over time [2-4]. It is different with clinical depression characterized by mood disturbances which affects daily life in long term period, in the form of moderate to severe depression between 4-12 months after delivery [5-8]. DSM IV (Diagnostic and Statistical of Mental Disturbances, classify psychic disturbances into three groups: Firstly, depression with minor symptoms which will disappear without treatment after five days; secondly, major depression a manifestation of severe depression; thirdly, psychosis which requires treatment $[9,10]$. It was reported that $50 \%$ of depression cases are not detected $[11,12]$. Depression may affect foetus development, temperament and behaviour of infants after birth, in which amongst children of 3-6 years old from depressed postnatal mothers, their IQ was lower than children of normal mothers [13].

Risk factors of postnatal depression consists of several factors, including first 90 days after delivery among primipara mothers with an incidence of $13 \%$, depression during pregnancy (10-20\% ); anxiety and stressful life experience during pregnancy and postnatal; lack of social support and depression history; women of reproductive age [4,14-16]. Other factors include family history of depression, bipolar disturbances, child abuse history, single mother, having children more than three, smoker, low social economic status, age of less than 18 and older than 35 years old, and lack of social support. Other risk factors include inability to cope with problems, social stress and unwanted pregnancy [17-19]. Risk factors in the developing countries consist of low educational levels and low payment job [20]. Biological risk factors comprise of hormonal factor, i.e., decreased serotonin, delayed reuptake from neurotransmitter $[21,22]$.
Currently, depression is the main contributor of disease burden among other mental health diseases, and is estimated to become second highest in ranking in 2020 [23]. It is estimated that the prevalence of postnatal depression in developing countries is $25 \%$, whereas in Asia is between $11-61 \%$ in which its $30 \%$ is among productive age women 20 50 years old [24]. In general, depression affects $6 \%$ of adults every year and is the main cause of suicide $[18,25,26]$.

In Indonesia depression is a serious mental health problem which requires proper response, whereas in the province of West Jawa, depression was ranked second highest amongst mental and emotional disturbances with a prevalence of 9, 3\%. Results of study in West Jawa found that $11-30 \%$ postnatal women experience an increased risk of depression [27,28]. Data from Statistic Office of Sukabumi city in 2010 indicated there were 7.498 births, in which 1.071 experiences obstetric disturbances during delivery $[27,29]$. However, data on prevalence of depression among postnatal women did not available in Sukabumi district 48 .

Depression during postnatal period among women is measured using Edinburgh Postnatal Depression Scale (EPDS) six days after delivery, in which score of bigger than 13 shows a severe depression

*Corresponding author: Poerwanto Siswo, Senior Lecturer, Physiotherapy Study Program, BinawanInstitute of Health Sciences, Jakarta, Indonesia, Tel: +62 (6221)80880882-8011777; E-mail: spoerwanto2006@gmail.com

Received November 13, 2016; Accepted January 16, 2017; Published January 20, 2017

Citation: Siswo P, Prasatwati E, Insriwati, Waluyo I, Subu AM, et al. (2017) The Outcome of Postnatal Exercise on Depressed Women Six to 16 Weeks afte Delivery in Sukabumi City, 2014: Pre and Post Intervention Study. J Health Med Informat 8: 247. doi: 10.4172/2157-7420.1000247

Copyright: (c) 2017 Siswo P, et al. This is an open-access article distributed unde the terms of the Creative Commons Attribution License, which permits unrestricted use, distribution, and reproduction in any medium, provided the original author and source are credited. 
Citation: Siswo P, Prasatwati E, Insriwati, Waluyo I, Subu AM, et al. (2017) The Outcome of Postnatal Exercise on Depressed Women Six to 16 Weeks after Delivery in Sukabumi City, 2014: Pre and Post Intervention Study. J Health Med Informat 8: 247. doi: 10.4172/2157-7420.1000247

Page 2 of 4

$[8,21,30,31]$. EPDS is easily used six weeks after delivery with sensitivity of $60 \%$ and specificity of $97 \% 23$, which is comparable with other measurement which ranges from $75-100 \%[8,23]$.

Various efforts have been used to reduce the depression duringand after delivery, such as antidepressant, hormonal and supplements $[32,33]$. In addition to pharmacological and psychological treatments, exercise is an effective treatment for depression, as indicated by results of study conducted among depressed women participated in intervention study which shows that exercise has a significant impact in lowering the depression [18,33-37]. It is associated with an increased level of certain chemicals in the brain through brain neurotransmitter called endorphin which interacts with brain receptors to reduce pain, stabilizes body temperature and pacify feelings [38]. It was also observed an increased body temperature, better blood flows resulted in axis hypothalamus-Hypophysis-adrenal, as well as physiological reactivity on stress $[39,40]$.

Post natal exercise is believed to strengthen muscle tone using additional load or body weight to resist the muscle contraction, which is done three times a week for ten weeks period. Post natal depression can be reduced by regular exercise such as walking, swimming, load exercise or jogging, which may create better mood [37,41]. It does not include high impact exercise such as running, jumping and aerobic exercise [42].

Post natal light exercise done at home will be more effective because post natal women should avoid fatique [43]. Recommended post natal exercise consists of systematic exercise using additional loads or body weight to resist muscle contractions, three times a week for 10 weeks. Women practising more post natal exercise will experience less depression than those who do not exercise [35].

Evidence shows that pregnancy and delivery are the main risk factors for depression during pregnancy and during post natal period, in addition to other factors. Statistic from West Jawa province and from the city of Sukabumi in West Jawa indicated the unavailability of data on post natal depression among women as measured by EPDS instrument. It was known that other than psychotherapy and antidepressant treatment applied to depressed women after delivery, light exercise and training has proved to have a beneficial impact to reduce post natal depression, even though the type of exercise was varied. In this analysis it was aimed to prove that post natal exercise has a beneficial impact to reduce the depression among women after delivery. The study question is therefore to observe the outcome of exercise among post natal women in Sukabumi city in 2014, during eight to sixteen weeks after delivery on depression as measured by EPDS score.

\section{Materials and Methods}

\section{Materials and settings}

The target population of this analysis was 120 women who delivered their babies in various health service units in the city of Sukabumi, West Jawa province in 2014, obtained from the Survey of the impact of Exercise and Slimmer on Maternal Health condition, physical fitness, mental health and hormonal status among delivering women in hospitals in Sukabumi city in 2013. Out of 120 women, it was selected study sample of 14 postnatal depressed women using the following sample size.

In which from previous study by Drietsa et al., 200949 it was found that difference $\sigma^{2}=11.42$; and $\sigma^{2}=12.51$. Given $80 \%$ power, $\mathrm{z}$ (beta) $=0.84$ and $\mathrm{Z}$ (Alfa)/2=1.96; it gives $\mathrm{n}=8.6$ (minimum size). The $\mathrm{n}$ is rounded up to 14.

The inclusion criteria includes: Women underwent normal delivery during postnatal period between 6 to 16 weeks; women who delivered in public health services in Sukabumi city, West Jawa province; at least second delivery (exclude primipara); suffer from postnatal depressionPND (EPDS $\geq 10$ ). All subject signed the informed consent.

\section{Methods}

The study design is an outcome evaluation of post natal exercise intervention in the framework of a Survey of the Impact of Exercise and Slimmer on Maternal Health condition, Physical Fitness, Mental Health and Hormonal Status among Delivering Women in Hospitals in Sukabumi City in 2013.

The main data sets of the main Survey consists of socio-demographic variables as well as various independent and dependent variables, such as pregnancy history including last pregnancy, disease history including back pain, anthropometric data (body weight, height, arm circumference, ratio of waist circumference and arm circumference, urine incontinence, hematologic data (insulin, triglyceride, LDL and HDL cholesterol, glucose and oestrogen.

As a partial study a sub-sample of 14 depressed subjects was selected from 120 main sampled women datasets. In this study those risk factors obtained from the main survey was not analysed. The outcome variable is Edinburgh Postnatal Depression Scale (EPDS) score, whereas the intervention is the post natal exercise. The measurement of EPDS was conducted before and after the exercise.

EPDS score was obtained using a questionnaire which consists of 10 items to be completed in around $5 \mathrm{~min}$ [44]. The response was recorded and scored between 0 and 3 , resulted in total score between 0 and 30 points. The cut-off point to determine possible depression is 10 . The higher the score the more likely the women suffer from depression.

The intervention regime consisted of postnatal exercises for 10 weeks @ 3 sessions per week or 30 sessions with 30-50 min exercise per session to be done in the morning before 10 O'clock and in the afternoon after 3 p.m. The exercise was done in a standing and lying down position. In standing position the movement consists of shoulders movement, bending with back in a straight position with nose to touch knees. In a lying down position, legs are bended and moved to the right and to the left, followed by lifting the buttock with pressure.

Univariate analysis was conducted to portrait the descriptive statistics of all selected variables collected among the sub-sampled women only, such as age, number of children, occupation and education, as well as depression before and after post natal exercise. Other data for other separated analysis such as anthropometric, pregnancy and delivery, back pain and haematological data was not analysed in this study. Central tendency and spread of data was presented for outcome variable, i.e., depression scale. Bivariate analysis was done to test the null hypothesis that EPDS is the same before and after postnatal exercise, assuming that no other variables influence the outcome.

\section{Results}

The characteristics of sample in terms of age, number of children, occupation and last educational status is presented in Table 1.

Majority of postnatal mothers was young between 20 and 35 years old (71.4\%), having two children (36\%), working mothers $(57 \%)$ and 
Citation: Siswo P, Prasatwati E, Insriwati, Waluyo I, Subu AM, et al. (2017) The Outcome of Postnatal Exercise on Depressed Women Six to 16 Weeks after Delivery in Sukabumi City, 2014: Pre and Post Intervention Study. J Health Med Informat 8: 247. doi: 10.4172/2157-7420.1000247

Page 3 of 4

have moderate education level (57\%). The following table (Table 2) indicated that the mean of depression scale decreased from 13.15 $(10.66,15.64)$ during pre-exercise down to $5.55(4.20,6.90)$.

Furthermore paired sample t-test of EPDS mean between preand post exercise shown in Table 3 indicated that there was a highly significant difference of 7.60 point $(\mathrm{p}<0.05)$.

Prior to conducting t-test, normal distribution data was confirmed using Shapiro-Wilkinson test. Finally, Monte Carlo test was conducted, and the results showed that after 10 weeks period of post natal exercise conducted among 14 depressed women, there was only one subject who was still depressed, but the other 13 women were normal with EPDS score $<10(\mathrm{p}<0.05)$.

\section{Discussion}

Results of this study indicated that the data was valid, as shown from the 95\% CI of the depression scale as shown in Table 2. The depression scale before intervention ranges from 12 to 15 among all 14 subjects, whereas after exercise was between 0 and 9 among 13 subjects, except one subject who still depressed. On average it was reduced by $60 \%$ or decreased by 7.6 point. We convinced that the efficacy of exercise in reducing the depression among post natal women was proven. Results of a systematic review and meta-analysis by Blamey et al. support this finding that exercise conducted among postnatal women reduced the postnatal depression (PND). Results of this study that observe a decreased depression was also shown by other study [28] (Elvira, 2006) who indicated that $50-85 \%$ of women experience psychic and psychological disturbances after delivery, but less depressed (statistically significant at $\mathrm{p}<0.05$ ) after underwent postnatal exercise despite one study that showed differently in which there was no significant decrease of depression after exercise intervention [18,34,4449]. In terms of biologic plausibility, it can be explained by the fact that by practising exercise regularly it will in turn increase the content of endorphin in the muscle which affects neurotransmitter in the brain to reduce depression. Endorphin will interact with receptors in the brain that stabilizes the body temperature and creates good feeling and mood [38].

\section{Conclusions}

Measurement of depression using Edinburgh Postnatal Depression Scale (EPDS) during pre- and post-exercise intervention among 14 women after delivery in the city of Sukabumi, West Jawa confirmed that the depression was reduced from an average scale of $13.15(10.66$,

\begin{tabular}{|c|c|c|}
\hline Socio-demographic data & n & $\%$ \\
\hline \multicolumn{3}{|c|}{ Maternal age } \\
\hline 20 years & 2 & 14.3 \\
\hline$>35$ years & 10 & 71.4 \\
\hline & 2 & 14.3 \\
\hline 2 & No. of children \\
\hline 3 & 2 & 14.3 \\
\hline 4 & 5 & 35.7 \\
\hline & 3 & 28.6 \\
\hline Household & Occupation & 21.4 \\
\hline Working & 6 & 42.9 \\
\hline & 8 & 57.1 \\
\hline Middle & Maternal education \\
\hline High & 8 & 57.1 \\
\hline
\end{tabular}

Table 1: Socio-demographic characteristics of sample by age, number of children, occupational status and education.

\begin{tabular}{|l|c|c|c|c|c|c|}
\hline \multicolumn{7}{|c|}{ Paired Samples Statistics-SPSS output } \\
\hline EPDS & Mean & $\mathbf{N}$ & $\mathbf{9 5 \%} \mathbf{~ C l}$ & Std. Deviation & Std. Error Mean \\
\hline & Post- Exercise & 5.55 & 14 & $4.20,6.90$ & 2.892 & 0.647 \\
\hline & Pre-Exercis & 13.15 & 14 & $10.66,15.64$ & 5.314 & 1.188 \\
\hline
\end{tabular}

Table 2: Paired samples statistics of EPDS mean pre and post exercise intervention.

\begin{tabular}{|c|c|c|c|c|c|c|c|}
\hline \multirow{2}{*}{ Mean Diff. } & \multirow{2}{*}{$\begin{array}{c}\text { Std. } \\
\text { Dev. }\end{array}$} & \multirow{2}{*}{ SE Mean } & \multicolumn{2}{|c|}{$\begin{array}{c}\text { 95\% CI Mean } \\
\text { Difference }\end{array}$} & \multirow{2}{*}{$\mathbf{t}$} & df & $\begin{array}{c}\text { Sig } \\
\text { (2-Tailed) }\end{array}$ \\
\cline { 3 - 7 } & & Lower & Upper & & & 0.000 \\
\hline-7.60 & 5.20 & 1.164 & -10.04 & -5.16 & -6.53 & 19 & 0.000 \\
\hline
\end{tabular}

Table 3: Paired samples test of EPDS mean pre and post exercise-SPSS output.

$15.64)$ to $5.55(4.20,6.90)$. The range of depression score was decreasing from moderate depression (score of 12-15) to normal (score of 0-9). This $60 \%$ reduction or 7.6 point of reduction was significant proving the efficacy of the post natal exercise to reduce the PND.

\section{Implications}

The study infers that the local District Health Office of Sukabumi may conduct preventive education to delivering women to practice postnatal exercise routinely and regularly. As it was also recommended in UK, National Institute for Health and Clinical Excellence recommended regime of exercise as part of the treatment for women during postnatal period with a new mild or moderate episode of PND [50].

\section{References}

1. Gavin NI, Gaynes BN, Lohr KN, Meltzer BS, Gart LG, et al. (2005) Perinatal Depression: A Systematic Review of Prevalence and Insidence. Obstet Gynecol 106: 1071-1083.

2. Simpson JA, Rholes WS, Campbell L, Tran S, Wilson CL (2003) Adult Attachment, The Transition to Parenthood and Depressive Symptoms. J Pers Soc Psychol 84: 1172-1187.

3. Canadian Mental Health Asossiation (2014) Postnatal Depression.

4. Stewart MD, Donna E (2011) Depressing During Pregnancy. NEJM 365: 16051611.

5. Roge T (2012) Depression; Family Medical Psychiatry Center.

6. Zieve D (2012) Postnatal Depression; ADAM Health Solutions.

7. Roxanne D, Edward MD (2014) Postnatal Depression. J Fam Psychol.

8. Dwenda K, Gjerdinger MD, Barbara P, Ywan MD (2007) Postnatal Depression Screening Importance, Methods, Barriers, and Recommendation for Practice. J Am Board Fam Med 20: 280-288.

9. https://en.wikipedia.org/wiki/DSM-IV_codes

10. Morgan PJ (2012) Postnatal Depression in a Primary-care Setting. Cln Advi.

11. Beth A, Lewis, Bethsy F, Kennedy MA (2011) Effect of exercise on Depression During Pregnancy and Postnatal. School of Kinesiology. Am J Life Style Med 5: 309-315.

12. Clark R, Tluczek A, Wenzel A (2003) Psychotherapy of Postnatal Depression: A Premilinary Report. Am J Ortho Psychiatry 73: 441-454.

13. Nulman I, Nulman I, Koren G, Rovet J, Barrera M, etal. (2012) Neurodevelopment of Children Following Prenatal Exposure to Venlafaxine, Selective Serotonin Reuptakelnhibitors, or Untreated Maternal Depression. Am J Psychiatry 169: 1165-1174.

14. Dietz PM, Williams SB, Callaghan WM, Bachman DJ, Whitlock EP, et al. (2007) Clinically Identified Maternal Depression Before, During, and After Pregnancies Ending in Live Births. Am J Psychiatry 164: 1515-1520

15. Pearlstein V, Margaret H, Amy S, Caron Z (2009) Postnatal Depression; Am J Gynecol 200: 357-364.

16. Robertson E, Grace S, Wallington T, Stewart DE (2004) Antenatal Risk Factors For Postnatal Depression: A synteshis of Recent Literature. Gen Hosp Psychiatry 26: 289-295.

17. Bahiyatun K (2009) Buku Ajar Asuhan Kebidanan Nifas Normal. Jakarta: Penerbit, EGC. 
Citation: Siswo P, Prasatwati E, Insriwati, Waluyo I, Subu AM, et al. (2017) The Outcome of Postnatal Exercise on Depressed Women Six to 16 Weeks after Delivery in Sukabumi City, 2014: Pre and Post Intervention Study. J Health Med Informat 8: 247. doi: 10.4172/2157-7420.1000247

18. Daley AJ, Jolly K, MacArthur C (2008) The Effectiveness of Exercise in The Management of Postnatal Depression: A systematic Review and MetaAnalysis. Fam Pract 26: 154-162.

19. Doucet S, Leterneau N (2009) Coping and Siucidal Ideations in Women with Symptoms of Postnatal Depression. University of New Brunswick, Hal, pp: 9-19.

20. Patel V, Merlyn R, Nandita DS (2002) Gender, Poverty, and Postnatal Depression: A Study of Mothers in Goa, India. Am J Psychiatry 159: 43-47.

21. http://www.sangath.com/images/file/Gender $\% 20$ Poverty $\% 20$ and $\% 20$ Postnatal\%20depression.pdf

22. Moran M (2003) Depression-Serotonin Link: Many Mysteries Remend. Am Pscyatr Assoc 38: 48-49.

23. Hewitt CE, Gilbody S, Brealey S, Paulden M, Palmer S, et al. (2009) Methods to Identy Postnatal Depression in Primary Care: An Integrated Evidence Syntesis and Value of Information Analysis. Health Technol Assess 13: 1-145

24. Ali NS, Ali BS, Azam IS, Kwamaja AK (2010) Effectiveness of Counseling for Anxiety and Depression in Mothers of Children Ages 0-30 Month by Community Workers in Karachi, Pakistan: A quasy Experimental Study. Biomed Centre 10: 57

25. Leicester (2010) Depression. Br Med J Nice Clin Guid.

26. Norman E, Sherburn M, Osborne RH, Galea MP (2010) An exercise and education program improves well-being of new mothers: a randomized controlled trial. Phys Ther 90: 348-355.

27. Dasar RK (2013) Badan Penelitian dan Pengembangan Kesehatan.

28. Elvira SD (2006) Depresi Pasca Persalinan. Jakarta: Fakultas Kedokteran Universitas, Indonesia.

29. Statistik BP (2012) Laporan Kesehatan Anak Kab/Kota Sukabumi. Biro Statistik Republik, Indonesia.

30. Perfetti J, Clark L, Fillmore CM (2004) Postnatal Depression; Identification, Screening, and Treatment. Wilconsin Medical Journal 103: 56

31. Sockol LE, Epperson CN, Barbe JP (2013) Preventing Postnatal Depression part 1: A meta-analysis of treatments for perinatal depression. Clin Psycho $\operatorname{Rev} 31: 839-849$

32. Blier P (2013) Neurotransmitter Targeting in the treatment of depression. Clin Psychiat J 74: 19-24

33. Dennis CL, Hodnett E (2007) Psychosocial and psychological interventions for treating postnatal depression. Cochrane Database Syst Rev 17: CD006116.

34. Rimer J, Dwan K, Lawlor DA, Greig CA, McMurdo M (2013) Exercise for depression. Cochrane Database Syst Rev 11: CD004366.
35. Marlene MD, Rachel V (2008) Exercise and Depression; MGH Center for Women Mental Health

36. Koltyn KF, Schultes SS (1997) Psychological effects of an aerobic exercise session and aa rest session following pregnancy. J Sports Med Phys Fitness 37: 287-291

37. Sexton MB, Byrd MR, Donohue OWT, Jacobs NN (2010) Web-based treatment for infertility-related psychological distress. Archives of women's mental health Springer Science \& Business Media B.V. 13: 347-358.

38. Lopez D (2011) Low Impact Exercise, Such as Hooping cans Case Stress, Depression and Anxiety.

39. Guszkowska M (2004) Effect of exercise on anxiety, depression and mood.

40. Petruzzello SJ, Landers DM, Hatfield BD, Kubitz KA, Salazar W (1991) A Metaanalysis on the anxiety-reducing effect of acute and chronic exercise. Outcomes and Mechanisms. Sports Med 3: 143-182.

41. Bobak (2005) Pengaruh Faktor Psikososial Terhadap Terjadinya Postnatal Blues Pada Ibu Nifas (Studi di Ruang Nifas RSUD R.A Bosoeni Mojokerto).

42. National Institute for Health Care Management-NIHCM (2011) Building a Stronger Evidence based for Employee Wellness Program. Washington DC USA.

43. Costa DD, Lowensteyn I, Abrahamowicz M, Ionescu-Ittu R, Dritsa M, et al. (2009) A Randomized Clinical Trial of Exercise to Alleviate Postnatal Depressed Mood. J Psychosom Obstet Gynaecol 30: 191-200.

44. Cox JL, Holden JL, Sagovsky R (1987) Detection of postnatal depression. Development of the 10-item Edinburgh Postnatal Depression Scale. Br J Psychiatry 150: 782-786.

45. Amstrong K, Edwards H (2003) The Effects of Exercise and Social Support on Mothers Reporting Depressive Symptoms: A pilot randomized controlled trial. Int J Ment Health Nurs 12: 130-138.

46. Gorczynski P, Faulkner G (2010) Exercise therapy for schizophrenia. Cochrane Database Syst Rev 12: CD004412.

47. Larun $L$ (2006) Exercise in prevention and treatment of anxiety and depression among children and young people. Cochrane Database Syst Rev 19: CD004691.

48. Statistik BP (2014) Laporan Kesehatan Anak Kab/Kota Sukabumi. Biro Statistik Republik, Indonesia.

49. Drietsa M, Dupuis G, Lowensteyn I, Costa DC (2009) Effects of home-based exercise on fatique in postpartu depressed women: Who is more likelyu to benefit and why? J Psychosom Res 67: 159-163

50. http://www.thelancet.com/pdfs/journals/lancet/PIIS0140-6736(13)60381-5.pdf 